\title{
Effect Of The Use Of Formats And Guidelines Of Integrated Emergency Nursing Care To The Accuracy And Completeness Of Nursing Documentation In The Emergency Departement Of The Regional Public Hospital Of Mas Amsyar Kasongan District And The Regional Public Hospital Of Pulang Pisau District Central Kalimantan
}

\author{
Suryagustina ${ }^{* 1}$ \\ ${ }^{1}$ Lecturer, Eka Harap School of Health Sciences Palangka Raya. \\ *gustin.yaya@yahoo.com
}

\author{
Karmitasari Yanra Katimenta ${ }^{1}$ \\ ${ }^{1}$ Lecturer, Eka Harap School of Health Sciences Palangka Raya. \\ karmitasari_yanra@yahoo.com
}

\author{
Dewi Apriliyanti ${ }^{1}$ \\ ${ }^{1}$ Lecturer, Eka Harap School of Health Sciences Palangka Raya. \\ Dewi_apriliyanti@gmail.com
}

\begin{abstract}
Objective: The objective of the study was to identify the effect of using integrated emergency nursing formats and guidelines on the accuracy and completeness of nursing documentation in the emergency departments.

Method: The design uses quasi experiments to determine the effect of using integrated emergency nursing formats and guidelines to the accuracy and completeness of nursing documentation at emergency departments regional public hospital Mas Amsyar Kasongan and regional public hospital Pulang Pisau. The sample of 39 people was divided into two groups. The experimental group consisted of 25 respondents and the control group consisted of 14 respondents. The results showed that there was a significant influence on the use of formats and guidelines of integrated emergency nursing care to the accuracy and completeness of nursing documentation in the emergency departments.

Results: The nursing implications of this study are for emergency care in providing immediate services while maintaining the quality of care and nursing documentation. The format and guidelines of integrated nursing care can be used to facilitate nurses in the documentation. For management can evaluate the performance of nursing, improve the standard of competence, and provide facilities according to the needs of patients.
\end{abstract}

Keywords: completeness of nursing documentation, emergency, format and guidance of nursing care, precision of nursing documentation.

\section{INTRODUCTION}

The emergency unit (ER) is a hospital service unit that provides the first service where the patient needs immediate action to save lives and prevent further disability [1]. Nursing care services provided by nurses at emergency departments use the nursing process. The nursing process is an approach to problem solving that enables nurses to organize and provide systematic and comprehensive nursing care [2]. Assessment on emergency cases is divided into two, namely: primary assessment and secondary assessment. Good cognitive, psychomotor, 
interpersonal, ethical, and problem-solving abilities are needed for assessment.

The nurse must ensure that the resulting data is documented and may be communicated to other health workers, otherwise it may be a proof-of-note for the person authorized and part of the nursing practice. The documentation process should take into consideration from the recording process to maintaining the quality of the records. Completeness and accuracy of data becomes a necessity in improving the quality of nursing care.

Documentation is generally less preferred by nurses because it is considered too complex, diverse, and time consuming. However, if the nursing care documentation is not done properly, completely, and accurately can degrade the quality of nursing care because it can not identify the extent to which the success level of nursing care has been given. It is important to modify the nursing plan in accordance with the evaluation of nursing in accordance with the conditions of patient development. The nursing care provided by the nurse must be sustainable depending on the patient's condition. Judging from the legal aspect, the nurse has no written evidence if the patient demands dissatisfaction with nursing services [3]. Factors that affect the completeness of the documentation of nursing care is a high workload of work motivation, job stress, leadership style, less harmonious human relationships, supervision of ineffective superiors, and possibly job saturation [4].

The results study on the application of nursing care standards in patients in September 2012 stated that an average of $61.9 \%$ with enough value categories; especially for documentation of the assessment stage of 55\% has been in accordance with the standards of nursing care. Berthiana's research was conducted in inpatient room at the regional hospital public hospital Buntok. The sufficient value here is that the nurse has not grouped the bio-psycho-social-spiritual data, the problem is not formulated according to the gap between the health status with the norm and the function of life, nursing diagnose not formulated in accordance with the problem, nursing diasnose not reflect the PE / PES and not actual, do not record the planning according to the diagnosis, are not prepared according to intervention priorities, do not perform documentation according to intervention, evaluation is done not referring to the purpose, as well as records that have not been written clearly and completely, and do not include nurse name, date and hour of nursing action. the reason for not completing the documentation is the lack of understanding of the standard of nursing care because there is no guidance in doing nursing care documentation [3].

The phenomenon is supported by the performance of nurses in implementing nursing care documentation at regional public hospital of Kelet atJepara district is mostly 
incomplete $79 \%$ incomplete. Research conducted by Pratiguna [5] that there is influence of pre accreditation of JCI (Joint Commission International) to completeness of medical record data of resume of inpatient in regional public hospital Dr. Moewardi Surakarta with complete completeness category which reached $64.22 \%$, and completeness of medical record data of resume of inpatient in regional public hospital Dr. Moewardi after pre accreditation into the complete category that reached $94.73 \%$. Completeness is meant here is composed of six resumes of patient service home. This could be one of the references to the use, guidance, and development of nursing assessment format at regional public hospital Mas Amsyar Kasongan. Visible improvement of the completeness of the patient's medical record resume data, so that the nurse is also able to make improvements in doing documentation with the format and guide that will researchers use in this research later.

According to the Ministry of Health on the emergency assessment should include primary and secondary assessment as well as biopsychosocial and spiritual conditions. The format used by the researcher in the study has been about primary and secondary assessment, as well as a review of allergy history, fall risk, psychological condition, socio-economic and spiritual conditions, communication and education needs, functional assessment (Bartel index), skin screening Norton scale), as well as nutritional screening. The format is holistic although in the usage of indirect execution must be complete filled in initial condition of patient entry, but for primary study and focus data must be complete. After the patient's condition is quite calm and stable then further study can be done. Most of the use of checklists (from assessment to nursing orders) in formatting will facilitate filling nurses and more efficient time. Implementation and evaluation should be written directly in accordance with the conditions experienced by patient in the fields that have been provided. Nursing care format is integrated with other health personnel so it is expected to occur effective communication between health workers. This format is adopted from Kemenkes, $\mathrm{MOH}$, JCI standards and the results of interviews with doctors and nurses working in the emergency unit at the RS that has been accredited plenary as well as hospitals to be used as research sites [7].

Interview conducted on 3 May 2016 at emergency departments regional public hospital Mas Amsyar Kasongan with head of the room and nurses said that they realize the implementation of nursing care documentation in the emergency departments is still not complete and needs to be updated. Stated that complete and correct documentation will facilitate information for the hospital. Complete documentation may be used for reference to health services, legal protection, information support, quality assurance, diagnosis, coding procedures, cost 
understanding, research, education, and as a support for hospital accreditation [8].

This research aims to determine the effect of the use of formats and guidelines of integrated emergency nursing care to the accuracy and completeness of nursing documentation in the emergency room regional public hospital Mas Amsyar Kasongan and regional public hospital Pulang Pisau.

\section{METHODS}

The design in this research was a quasi experimental design, explaining causal relationships involving the control group, where in this design the experimental group was treated while the control group did not [9]. The researcher purposively selected the experimental group (intervention) that has characteristic equality with the control group. The selection of this design is because the researcher wishes to evaluate the effect of intervention on the use of formats and guidelines of integrated emergency nursing care to the accuracy and completeness of nursing documentation.

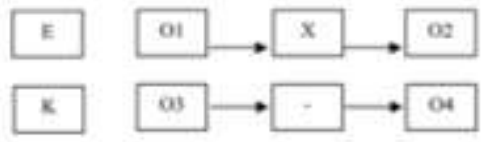

Figure 1. Research Design

The sample in this research using purposive sampling is 25 nurses who become the intervention group (given the format of integrated nursing care nursing and format filling guidance) at the emergency departments of regional public hospital. Mas Amsyar
Kasongan and 14 nurses who became the control group (keep using the existing format) at regional public hospital Pulang Pisau. Time of research is the time period needed by the writer to get research data which is executed, that is on July-September 2017.

The instrument of this research refers to instrument A of the Ministry of Health [10], which includes observations for the accuracy of documentation amounted to 22 questions and for the observation of documentation completeness amounted to 29 questions.

Validity test was conducted on 16 pieces of nursing care documentation at the hospital. Then the next researcher performs construct validity, expert test, and legibility test. Data analysis was done by univariate and bivariate analysis. Univariate analyzes (proportions and central tendencies) were performed on the characteristics of respondents consisting of sex, age, duration of work, attended training, and, education and accuracy and completeness of the documentation before and after the format and guidance of the control group and intervention. Bivariate analysis was done to see the difference of each dependent and independent variable, the difference is considered significant if the $p$ value is <level of significance $(<5 \%=0,05)$. The data analysis is 2 for paired differential test (Wilcoxon test) and unpaired test (Mann-Whitney). The ethical principle of research remains to be done to protect the subject of research. 


\section{RESULT}

The analysis is performed on the accuracy variable of the documentation and the completeness of the nursing documentation.

Table 1. Results of Analysis on Control \& Intervention Groups on Documentation Accuracy After being given Format and Integrated Guidance at emergency departments regional public hospital Mas Amsyar Kasongan and regional public hospital Pulang Pisau Central Kalimantan Year $2017(\mathrm{~N}=39)$

\begin{tabular}{|c|c|c|c|c|c|}
\hline & $\mathrm{N}$ & Mean & $\begin{array}{c}\text { Media } \\
\mathrm{n}\end{array}$ & SD & $\begin{array}{c}\mathrm{P} \\
\text { valu } \\
e\end{array}$ \\
\hline \multirow{4}{*}{$\begin{array}{l}\text { Group } \\
\text { control } \\
\text { Group of } \\
\text { interventio } \\
\text { ns }\end{array}$} & 1 & 16.2 & 18.18 & 2.93 & \multirow{4}{*}{$\begin{array}{c}0.00 \\
0\end{array}$} \\
\hline & 4 & 3 & & & \\
\hline & 2 & 85.2 & 86.40 & 10.1 & \\
\hline & 5 & 7 & & 1 & \\
\hline
\end{tabular}

Based on the above table, the accuracy of the documentation after the format and guidance of emergency nursing care was integrated in the intervention group of median difference of 69.04 to the non-intervention control group, the deviation standard difference of 7.18, and Mann-Whitney test result obtained $\mathrm{p}$ value $0.000<\alpha 0.05$ shows that there is a very significant difference to the accuracy of the documentation between the control group and the intervention group.

Table 2. Results of Analysis on Control \& Intervention Groups on Completeness of Documentation After being given Format and Integrated Guidance in regional public hospital Mas Amsyar Kasongan and regional public hospital Pulang Pisau Kalimantan Tengah Year $2017(\mathrm{n}=39)$

\begin{tabular}{lccccc} 
& $\mathrm{N}$ & Mean & Median & SD & P value \\
\cline { 2 - 6 } $\begin{array}{l}\text { Group } \\
\text { control }\end{array}$ & 14 & 22.41 & 24.14 & 2.2 & \\
$\begin{array}{l}\text { Group of } \\
\text { interventio }\end{array}$ & 25 & 77.80 & 79.30 & 14. & 0.000 \\
ns & & & & 02 & \\
\hline
\end{tabular}

The table above illustrates the completeness of the documentation after the format and guidance of integrated emergency nursing care in the intervention group with a mean difference of 55.39 to the nonintervention control group, the deviation standard deviation of 11.78 , and the MannWhitney test results obtained p value $0.000<\alpha$ 0.05 indicates that there is a very significant difference to the completeness of the documentation between the control group and the intervention group.

\section{DISCUSSION}

The statistical test of documentation accuracy after given the format and guidance of integrated emergency nursing care obtained a mean difference of 69.04 with the deviation standard difference of 7.18, and MannWhitney test result with $p$ value $0.000<\alpha 0.05$. There was a significant difference between control and intervention groups. While the completeness of the documentation was tested statistically after given the format and guidance of care of integrated emergency nursing care obtained difference of 55.39 with difference of standard deviation 11.78, and Mann-Whitney test result with $\mathrm{p}$ value 0.000 $<\alpha$ 0.05. There was a significant difference between control and intervention groups.

Beneficial nursing process facilitates nursing documentation, where necessary accuracy and completeness of nursing documentation. The result of the statistic test indicates that there is an influence of intervention in the intervention group, it requires a regular and systematic method to provide care to the client. It is necessary to set 
standardization of nursing practice and nursing documentation so as to improve the efficiency of nursing, economics, and improve the quality of service through the use of deliberate action [11].

The results of research conducted by Mastini [12] showed that respondents with good knowledge with the completeness of documentation as much as $83.3 \%$ and respondents with less knowledge with the completeness of documentation is not appropriate as much as $86.4 \%$. Knowledge relates to the completeness of documenting nursing care ( $\mathrm{p}$ value $<0.05)$.

Knowledge is the result of knowing and this happens after the person does the sensing of a particular object. Rejection of a particular object. Sensing occurs through the five senses of the human senses of sight, hearing, smell, taste and touch. Knowledge is a very important domain in shaping one's actions. Much of human knowledge is obtained through the eyes and ears. Knowledge can also be gained from formal and informal education [13].

Behavior based on knowledge will be more lasting than behavior that is not based on knowledge. But the increase in knowledge does not always reflect behavioral changes. Some factors that influence a person's behavior are knowledge and attitude, but the formation of behavior itself is not solely based on it but is still influenced by many very complex factors [13].
Knowledge according to Locke which explains that after humans get the inf ormation will be processed further by thinking, processing, questioning, classifying and reflected. This good knowledge should be maintained by digging deeper into the knowledge of documenting nursing care by reading and applying the documentation guidelines.

The intervention group that is given the format of nursing care and that has been disseminated about the guidelines and how to fill the nursing care has a significant impact on the accuracy and completeness in documenting the nursing care, it is in accordance with the theory and the results of related research that with a given explanation or knowledge can increase a person's ability to act in relation to nursing care and nursing documentation.

Based on the results of research conducted by Berthiana [3] that related to the accuracy of filling nursing documentation is nurse motivation with $\mathrm{p}$ value 0.008 . The relationship is statistically significant so that it can be said that the higher the motivation of a treatment will affect the accuracy of nursing care documentation.

It is appropriate that motivation is the driving force which affects a person or member of the organization willingly to surrender the ability in the form of expertise, or skills, personnel and time to organize the various activities that are his responsibility and fulfill his obligations in the context of achieving the objectives and organizational 
goals that have been determined previous. Motivation is needed to improve nursing care documentation activities with good supervision, reward and punishment must be done to improve good documentation.

\section{CONCLUSION}

The use of integrated emergency nursing formats and guidelines affects the accuracy and completeness of emergency nursing care documentation in emergency departments rooms.

\section{REFERENCES}

[1] Law of the Republic of Indonesia Number 44 Year 2009 About Hospital.

[2] Potter, Patricia A. \& Perry, Anne G. (2009). Fundamentals of Nursing. Buku 1. Edisi 7. Jakarta: Salemba Medika.

[3] Berthiana. (2012). Hubungan Motivasi Kerja Perawat Dengan Ketepatan Pengisian Dokumentasi Asuhan Keperawatan Di Ruang Rawat Inap RSUD Buntok 2012. Jurnal Managemen Keperawatan. Volume 1, Number 1, May 2013: 57-72.

[4] Tamaka, Ryny Silvana., Mulyadi, \& Malara, Reginus. (2015). Hubungan Beban Kerja Dengan Pendokumentasian Asuhan Keperawatan Di Instalasi Gawat Darurat Medik RSUP. Prof. DR. R.D. Kandou Manado. ejournal Keperawatan $(e-K p)$. Volume 3, Number 2, May 2015.

[5] Pratiguna, Agnes Aroma. (2012). Pengaruh Pre Akreditasi JCI (Joint Commission International) Terhadap Kelengkapan Data Rekam Medis Resume Pasien Rawat Inap Di Rumah Sakit Dr. Moewardi Surakarta. Jurnal Ilmiah rekam Medis dan Informatika
Kesehatan. Volume II, Number 2, September 2012. ISSN: 2086-2628.

[6] Kemenkes RI. (2011). Standar Akreditas Rumah Sakit, Kerjasama Direktorat Jenderal Bina Upaya Kesehatan Kementerian Kesehatan Republik Indonesia dengan Komisi Akreditasi Rumah Sakit (KARS). Jakarta.

[7] Depkes RI.. (2010). Prinsip Umum Pelayanan IGD di Rumah Sakit. Jakarta.

[8] Hasanuddin, Slamet. \& Kurniadi, Arif. (2012). Analisis Ketidaklengkapan Dokumen Rekam Medis Rawat Inap Ruang An Nisa Triwulan I Tahun 2012 Di RSU PKU Muhammadiyah Gubug. Faculty of Health Unidas.

[9] Nursalam. (2011). Manajemen Keperawatan. Edisi 3. Jakarta: Salemba Medika.

[10] Depkes RI. (2005). Sistem Penanggulangan Gawat Darurat Terpadu. Jakarta.

[11] Lapham, Jeremy. (2014). Project: Ghana Emergency Medicine Collaborative. Nursing Process and Linkage between Theory and Practice. University of Michigan.

[12] Mastini, I.G.A.A. Putri. (2013). Hubungan Pengetahuan, Siakp, Dan Beban Kerja Dengan Kelengkapan Pendokumentasian Asuhan Keperawatan Irna Di Rumah Sakit Umum Pusat Sanglah Denpasar. Tesis, Universitas Udayana.

[13] Notoatmodjo, Soekidjo. (2003). Pendidikan Dan Perilaku Kesehatan. Rineka Cipta. Jakarta. 